\title{
УДК 339.16.012.34:[658.310.13:005]](045)
}

\section{ПРОЦЕСНИЙ МЕНЕДЖМЕНТ ЯК ІНСТРУМЕНТ ЕФЕКТИВНОГО ФУНКЦІОНУВАННЯ ТОРГОВЕЛЬНИХ ПІДПРИЕМСТВ СПОЖИВЧОЇ КООПЕРАЦІї}

\author{
Світлана Філіна \\ ВНЗ Укоопспілки «Полтавський університет економіки і торгівлі», \\ Полтава, Украӥна
}

Резюме. Досліджено внутрішні проблеми розвитку менеджменту підприємств споживчоі кооперації, які зумовлені необхідністю реалізачї практичних заходів до побудови механізму управління торговельними підприємствами споживчої кооперації. Визначено роль процесного менеджменту як фактора підвищення ефективного функціонування торговельних підприємств споживчої кооперації за рахунок досконалої реалізації його базових функцій. На основі узагальнення результатів досліджень сучасних учених та змісту основного законодавчого акта визначено, щзо на внутрішні проблеми розвитку підприємств споживчої коопераџії впливає неспроможність пристосуватися до змін ринку та забезпечити свій конкурентоспроможний розвиток через неефективний менеджмент. Досліджено проиесний менеджмент, основна парадигма та головний ефект якого полягає в максимальній гнучкості та швидкій адаптаиії до загроз, щчо надходять із зовнішнього середовища, тому що в рамках цього підходу до управління переважно використовуються горизонтальні структури взаємодії та практично немає ієрархії. Надано рекомендації щзодо ефективного функиіонування підприємств споживчої кооперації на засадах прочесного менеджменту, серед яких є зміна способу мислення, зокрема усвідомлення діяльності підприємства у розрізі бізнес-прочесів, щцо є домінуючими для торговельних підприємств. Визначено переваги прочесного менеджменту, серед яких його спрямованість на кінцеві результати ефективної діяльності в рамках кожного бізнес-процесу й ефективне забезпечення підприємством проиесу задоволення потреб споживачів. Доведено, що впровадження процесного менеджменту - основне управлінське завдання, вирішення якого сприяє визначенню механізмів реалізації бізнес-процесів, щзо забезпечують оптимізацію тривалості циклу постачання та продажу товарів $i$ надання якісних торговельних послуг, щчо підвищить ефективність управління та діяльності торговельних підприємств.

Ключові слова: управління, процесний менеджмент, бізнес-процес, базові функції, підприємство, споживча кооперація.

https://doi.org/10.33108/galicianvisnyk_tntu2019.06.126

Отримано 08.12.2019

UDC 339.16.012.34:[658.310.13:005]](045)

\section{PROCESS MANAGEMENT AS AN INSTRUMENT OF EFFECTIVE FUNCTIONING OF TRADE CONSUMER COOPERATION ENTERPRISES}

\author{
Svitlana Filina

\section{Poltava University of Economics and Trade, Poltava, Ukraine}

\begin{abstract}
Summary. The objective of the paper is to investigate the internal problems of management development of consumer cooperation enterprises, which are caused by the need to implement the practical measures concerning the development of the mechanism for managing trade consumer cooperation enterprises. The role of process management as a factor of increasing the effective functioning of trade consumer cooperative enterprises, due to the perfect implementation of its basic functions is defined in this paper. Based on the generalization of the investigation results by modern scientists and the content of the basic legislative act, it is determined that the internal problems of the development of consumer cooperation enterprises are affected by the inability to adapt to the market changes and to ensure their competitive development through inefficient management. Process management, the main paradigm and the main effect of maximum flexibility and rapid adaptation to the threats of the external environment is investigated, as horizontal management structures are used mainly in this management
\end{abstract}


approach and there is practically no hierarchy. Recommendations concerning the effective functioning of consumer cooperation enterprises on the basis of process management including the change in the way of thinking, particularly, awareness of the enterprise activity in terms of business processes that are dominant for trade enterprises are given. The advantages of process management, including its focus on the final results of effective activity within each business process and effective provision of the enterprise with the process of meeting the needs of consumers are identified. It is proved that implementation of process management is the main management task, the solution of which contributes to the determination of the business processes implementation mechanisms providing optimization of the duration of delivery cycle and sale of goods and quality trade services provision, which will increase the trading enterprises management efficiency and activity. cooperation.

Key words: management, process management, business process, basic functions, enterprise, consumer https://doi.org/10.33108/galicianvisnyk_tntu2019.06.126

Received 08.12.2019

Постановка проблеми. У сучасних умовах в Україні відбуваються глибокі економічні зміни, активно формуються нові підходи до управління економікою, впроваджуються нові ринкові методи господарювання. Результати досліджень українських учених свідчать, що саме в цих умовах «...на вітчизняних підприємствах відбувається активний перехід від адміністративної форми управління до використання сучасних підходів до менеджменту, що дозволило підприємствам економічно розвинених країн зайняти конкурентні позиції на світовому ринку» [1, с. 7].

На тлі становлення вітчизняного ринку та зростання конкуренції всередині системи споживчої кооперації почали послаблюватися економічні зв'язки, зменшуватися обсяги та показники її господарської діяльності. Тим часом свою діяльність активізували приватні вітчизняні й іноземні товаровиробники та торговельні мережі. Завдяки скоординованій i централізованій на загальнодержавному рівні господарській діяльності, а також значним інвестиціям вони почали витісняти з ринку підприємства споживчої кооперації. Це зумовлено насамперед тим, що система споживчої кооперації не повною мірою адаптувалася до нових умов господарювання та нового законодавства. Якщо такі тенденції збережуться й надалі, то існує ймовірність, що за кілька років споживчу кооперацію України очікуватиме системна криза, яка може призвести до негативних наслідків.

Упровадження процесного менеджменту зумовлене необхідністю реалізації практичних заходів щодо побудови механізму управління процесами на засадах процесного менеджменту, які відповідатимуть сучасним умовам функціонування торговельних підприємств СК.

Аналіз останніх досліджень і публікацій. Водночас, на сучасному етапі розвитку СК існує низка проблем, які, з одного боку, є наслідком переходу національної економіки на ринкові важелі управління, а 3 іншого, - безпосередньо стосуються неефективного менеджменту на підприємствах цього сектора економіки. Ученийекономіст Н. О. Макухіна звертає увагу у своїх дослідженнях на першочергові проблеми, і доводить, що «повільне і здебільшого суперечливе реформування економіки, тривала економічна криза, лібералізація економічних відносин, правова невизначеність, посилення конкуренції на ринку споживчих товарів суттєво послабили економічну стабільність i конкурентоспроможність торговельних підприємств споживчої кооперації» [2, с. 1]. У свою чергу, Н. С. Свстафієва пов'язує цю проблему з «...істотним руйнуванням ресурсного потенціалу кооперації в умовах глобальної кризи, важким соціальним станом сільського населення, складною соціально-демографічною ситуацією, низьким соціально-культурним рівнем розвитку села» [1]. Докорінні причини виникнення вищезгаданих проблем С. Р. Семів пояснює відсутністю належної державної підтримки, неконкурентоспроможністю підприємств СК у порівнянні з приватними та закордонними торговельними посередниками різних типів [3, с. 205].

На нашу думку, неспроможність пристосуватися до цих змін і забезпечити свій конкурентоспроможний розвиток $\epsilon$ проблемою неефективного менеджменту у СК, про що свідчать аргументи дослідження саме цього вченого-економіста: «Недостатній рівень 
менеджменту, нехтування керівників науково обгрунтованими методиками визначення ефективності торговельних операцій, недостатній рівень забезпечення кваліфікованими кадрами, неузгодженість дій між членами системи кооперації, помилки у виборі партнерів і ціноутворенні, зниження ефективності виробництва та реалізації продукції, невикористання потенціалу ефекту від масштабних операцій...» [3, с. 207].

Метою дослідження $\epsilon$ визначення ролі процесного менеджменту як фактора підвищення ефективного функціонування торговельних підприємств споживчої кооперації за рахунок досконалої реалізації його базових функцій.

Постановка завдання. Для досягнення поставленої мети визначено такі наукові завдання: узагальнити результати досліджень сучасних учених щодо внутрішніх проблем розвитку менеджменту підприємств СК; розкрити та проаналізувати джерела інформації, що забезпечують взаємозв'язок між базовими функціями процесного менеджменту щодо ефективного функціонування підприємств СК; дати рекомендації щодо ефективного функціонування підприємств споживчої кооперації на засадах процесного менеджменту.

Для вирішення поставлених завдань було використано такі методи: аналіз, синтез, узагальнення, індукція, аналогія, системний підхід.

Виклад основного матеріалу. За своєю природою СК є соціально-економічною системою, мета якої полягає в реалізації як соціальних, так і економічних завдань за допомогою сучасних ефективних методів менеджменту [4, с. 8].

Відповідно до ст. 1 Закону України «Про споживчу кооперацію», споживча кооперація - це «...добровільне об'єднання громадян для спільного ведення господарської діяльності з метою поліпшення свого економічного та соціального стану. Вона здійснює торговельну, заготівельну, виробничу та іншу діяльність, не заборонену чинним законодавством України, сприяє соціальному і культурному розвитку села, народних промислів і ремесел, бере участь у міжнародному кооперативному русі» [6]. На основі цього базового визначення зробимо висновок про те, що для розвитку підприємств СК необхідно використовувати широкий спектр інструментів менеджменту, які адаптовані як до виробничої, так і торговельної, заготівельної та інших видів діяльності.

Функції та механізми процесного менеджменту повинні охоплювати кожен ланцюг будь-якого підприємства або організації СК, що здійснюють господарську діяльність. Вона проявляється у закупівлі, збереженні, реалізації товарів і послуг з метою задоволення потреб ринку та являє собою господарський комплекс.

Розвиток торговельних підприємств у СК на основі процесного менеджменту має певну специфіку: створюючи нову споживчу вартість, вони надають послуги 3 просування товарів від виробників до споживачів, а також здійснюють обслуговування споживачів у процесі продажу товарів. Рівень розвитку торгівлі завжди був своєрідним індикатором суспільного відтворення й добробуту громадян.

3 огляду на вищевикладене, необхідно вжити заходи, спрямовані на підвищення рівня конкурентоспроможності підприємств такого стратегічно важливого сектора економіки України, як споживча кооперація загалом, зокрема торговельних підприємств. Міжнародний досвід свідчить, що удосконалення менеджменту саме в кооперативному секторі є основою ефективного функціонування [5, с. 1].

Узагальнивши результати досліджень сучасних учених, ми дійшли висновку, що на внутрішні проблеми розвитку підприємств СК з погляду усунення протиріч у системі менеджменту дослідники звертають недостатньо уваги. На наш погляд, це пов'язано, перш за все, з тим, що чинне законодавче поле зумовлює самостійність суб'єктів СК у виконанні функцій управління в своїй діяльності. Зокрема, проаналізувавши зміст ст. ЗУ «Про споживчу кооперацію», зауважимо, що «...споживча кооперація незалежна у своїй діяльності від органів державного управління, політичних та інших громадських організацій. Забороняється будь-яке втручання, що може обмежувати права споживчої кооперації або перешкоджати їх здійсненню, якщо це не передбачено законом» [6]. Отже, 
сфера державного втручання в менеджмент на підприємствах (в організаціях, установах) СК є мінімальною. Для цього, відповідно до ст. 7 Закону України «Про споживчу кооперацію», обирається керуючий орган, на який покладається використання всіх функцій управління - «...загальні збори членів споживчого товариства, які... обирають керівні та контрольні органи товариства, а також вирішують інші питання, пов'язані 3 його діяльністю...». Виходячи з норм цієї статті, можна стверджувати, що контрольній функції управління відведено провідну роль. Про це йдеться у ст. 15: «Ревізії фінансовогосподарської діяльності споживчих товариств, спілок та підпорядкованих їм підприємств проводяться їх ревізійними комісіями (ревізорами) або контрольноревізійним апаратом відповідних спілок чи аудиторськими організаціями». Саме у цій статті приділено значну увагу пов'язуючій функції процесного менеджменту інформаційно-комунікаційній, а саме: «Споживчі товариства та їх спілки проводять облік результатів своєї діяльності, складають статистичну інформацію та адміністративні дані в порядку, встановленому законодавством, i несуть відповідальність за їх достовірність. Вимога іншої інформації, не встановленої законодавством, забороняється». Базовою функцією процесного менеджменту $\epsilon$ «мотивація», про яку йдеться у ст. 14 вищезазначеного Закону України: «Споживчі товариства та їх спілки сприяють забезпеченню зайнятості населення шляхом створення робочих місць, розширення мережі підприємств, застосування гнучкого режиму праці, організації професійної підготовки, перепідготовки та підвищення кваліфікації працівників, передусім тих, які є членами споживчих товариств. Споживчі товариства, їх спілки та підпорядковані їм підприємства мають право наймати та звільняти працівників, ... самостійно встановлювати форми, системи і розміри оплати праці осіб, які працюють за наймом; ... гарантують своїм працівникам оплату праці відповідно до професії, кваліфікації та особистого трудового внеску, належні умови праці, а також забезпечують соціально-економічні гарантії, передбачені законодавством України... Для охорони здоров'я і профілактики захворювань працівників у системі споживчої кооперації створюється мережа лікувально-профілактичних, санаторно-курортних та оздоровчих закладів» [6].

Отже, аналіз змісту основного законодавчого акта, що регламентує діяльність СК в Україні, показав, що права менеджерів підприємств (організацій, установ) не є обмеженими, вони можуть використовувати як базові, так і зв'язуючі функції управління.

Прийняття цього законодавчого акта повинно було сприяти розв'язанню накопичених проблем управління, становленню та розвитку СК Україні, які на кожному етапі мали свої специфічні риси. Наприклад, недоліком управління в організаціях і на підприємствах СК повоєнного часу була зорієнтованість менеджменту, в першу чергу, на функціональний підхід до управління та на дії вищих органів управління, що позбавляло менеджерів самостійності ведення господарської діяльності. Недоліком управління 80-х pp. XX ст., на наш погляд, було те, що внутрішня структура СК загалом та ії організацій і підприємств, яка остаточно сформувалася як лінійно-функціональна. Структура управління характеризувалася наявністю значної кількості підрозділів в апараті управління, неузгодженістю між результатами діяльності підрозділів; їх оцінкою, низькою мотивацією працівників, високою концентрацією повноважень щодо прийняття рішень вищого керівництва, недостатнім розповсюдженням принципів колегіальності, хоча це один із принципів кооперації, недотримання якого суттєво порушує принципи функціонування СК.

Недоліки управління за період 1985-1991 рр. пояснюються кризовим станом кооперативної системи, втратою значної частини ресурсного потенціалу, скороченням внеску в загальні макроекономічні показники, скороченням обсягу кооперативного товарообігу, грошових доходів та інвестиційних нагромаджень, погіршенням технологічного та організаційного стану, скороченням кількості робочих місць. Унаслідок негативних тенденцій цього періоду, коли пріоритетною була лінійно- 
функціональна організаційна структура управління, відбулося скорочення низки обслуговуючих підрозділів, посилилася роль підрозділів, що проводять комерційну діяльність. Значно погіршився соціальний клімат на підприємствах і в організаціях СК, знизилася трудова мотивація внаслідок збільшення кількості неоплачених відпусток i затримання заробітної плати, звільнилася значна кількість найбільш кваліфікованих кадрів і скоротилася частка молодих фахівців. При цьому майже не змінився керівний склад.

Отже, після прийняття законодавчого акта 1992 р., який вивів за межі державного управління СК України, перед менеджерами постало завдання - розв'язати проблему подолання зазначених кризових явищ, знайти напрями адаптації системи до нових умов господарювання, реформування відносин власності. На початку цього періоду почалося відновлення господарських зв'язків, змінився керівний склад, покращився фінансовий стан СК і відновилися іiі ринкові позиції. Водночас, створене потужне законодавче підгрунтя, зміна внутрішньої організаційної та управлінської структури СК мали хаотичний і досить формальний характер. Тому була потреба в суттєвому реформуванні менеджменту з метою перегляду повноважень і відповідальності керівництва, усунення перенавантаженості оперативною діяльністю вищої ланки управління.

Специфіка управління СК полягає в комплексності процесу управління, що, у свою чергу, вимагає від організації процесу управління дотримання принципу поєднання різних видів діяльності. СК поєднує різні сфери: виробничу, громадську та сферу обслуговування, що є проявом ряду особливостей управління на основі процесного менеджменту.

Аналіз проблем менеджменту на підприємствах СК в еволюційному аспекті, показав, що «...у різні періоди розвитку економіки України закладалися передумови для створення ефективної системи споживчої кооперації, але водночас виникали певні протиріччя в самій системі управління нею, з якими доводиться мати справу на практиці й сьогодні. Кожен період відображає нову стадію розуміння системи управління споживчою кооперацією, iї соціальних і економічних проблем, розроблення способів їх розв'язання...» [7].

Основна парадигма та головний ефект процесного менеджменту полягає в максимальній гнучкості та швидкій адаптації до загроз, що надходять із зовнішнього середовища, тому що в рамках цього підходу до управління переважно використовуються горизонтальні структури взаємодії та практично немає ієрархії.

Процесний менеджмент $є$ принципово новим підходом, який суттєво відрізняється від традиційного підходу до управління. Його виникнення зумовлене агрегованим впливом невизначеності та нестабільності середовища господарювання. На тлі класичного функціонального менеджменту перехід до процесного менеджменту був, з одного боку, логічно пристосованим до змін навколишнього середовища, а з іншого, теорії управління.

Згідно 3 Я. Броком та М. Роземаном інструменти процесного менеджменту дозволяють користувачам сформувати бачення - виділити та виробити стратегію функцій і процесів, визначити базовий процес або процес покращення, провести моделювання - імітувати зміни в цьому процесі, проаналізувати - порівняти різні моделі для визначення оптимальних позитивних змін, покращити - вибрати й упровадити форму, контролювати, провести реінжиніринг, реконструювати процеси «з нуля» для підвищення результатів [8].

Процесний менеджмент - це сукупність операцій або дій 3 планування, кординування, заохочення та моніторингу реалізації процесу. Особливо часто процес помилково розуміють як реінжиніринг. Іноді процесний менеджмент включає реінжиніринг, або реінжиніринг включає процесний менеджмент. Але процесний менеджмент - це застосування знань, умінь, інструментів, технологій і систем для визначення, візуалізації, оцінювання, контролю, звітування та вдосконалення процесів із метою вигідного врахування вимог споживачів [9, с. 18]. 
Н. О. Мухіна пропонує відновити економічну стабільність торговельної галузі для подальшого розвитку СК, удосконаливши управління на основі системної інформатизації торговельних бізнес-процесів і формування інформаційно-аналітичної бази для прийняття управлінських рішень як на рівні торговельного підприємства, так i на всіх рівнях системи споживчої кооперації [2]. Ми поділяємо погляди дослідниці, оскільки ці заходи сприятимуть вирішенню низки питань щодо координації робіт із формування інформаційного забезпечення та формалізації методів обліку, аналізу, планування, прийняття рішень, розроблення підходів системної організації інформаційного забезпечення управління бізнес-процесами торговельного підприємства. Л. А. Рибалко зазначає, що застосування системного підходу сприяє формуванню системи управління якістю в СК $[10$, с. 2]. Ця думка заслуговує на увагу, оскільки для формування системи управління якістю безпосередньо на підприємствах торгівлі СК науковець використовує процесний підхід із метою формування процесної моделі в торгівлі та впровадження стандарту IDEF0 підприємствами торгівлі при створенні моделі сукупності процесів.

Сучасні вчені у ході дослідження проблем розвитку підприємств СК особливу увагу приділяють взаємозв'язку між базовими функціями процесного менеджменту. Зокрема Ю. О. Ночовна у своїх дослідженнях звертає особливу увагу на те, що «...ефективно організована система управлінського обліку за допомогою відповідного інструментарію здатна забезпечити формування необхідної економічної інформації та сприяти успішній реалізації основних функцій управління: планування, обліку, контролю, аналізу та оцінювання діяльності, регулювання, обміну інформацією, мотивації та стимулювання, прийняття управлінських рішень» [11, с. 3]. Таким чином, інформаційна функція з погляду процесного менеджменту виконує зв'язувальну роль між базовими функціями управління. Ми поділяємо думку дослідниці, що саме на цій основі органічно поєднується системний і процесний підходи для «...визначення елементно-інтегрованої цілісності управлінського обліку як передумови формування його теоретичних, організаційних і методичних засад і використання у цій системі окремих методів управління для збирання, опрацювання та передавання інформації внутрішнім користувачам із метою прийняття управлінських рішень щодо ефективності діяльності» [11, с. 8].

Розвиток національної економіки значною мірою залежить від ефективної діяльності провідної галузі - роздрібної торгівлі, яка виконує роль економічного двигуна для всіх інших галузей, здійснюючи ринкове узгодження споживчого попиту та пропозиції. Торгівля відіграє важливу роль - забезпечує зв'язок між виробництвом та споживанням, задовольняє платоспроможний попит населення, завершує процес розподілу, зміцнює фінансову систему та грошовий обіг підприємств.

Висновки. Дослідження процесного менеджменту як фактора підвищення ефективного функціонування торговельних підприємств споживчої кооперації дозволило виділити науково-прикладні проблеми, серед яких є зміна способу мислення, зокрема усвідомлення діяльності підприємства у розрізі бізнес-процесів, що $\epsilon$ домінуючими для торговельних підприємств. При цьому перевагою процесного менеджменту $є$ його спрямованість на кінцеві результати ефективної діяльності в рамках кожного бізнес-процесу й ефективне забезпечення підприємством процесу задоволення потреб споживачів. Упровадження процесного менеджменту - основне управлінське завдання, вирішення якого сприяє визначенню механізмів реалізації бізнеспроцесів, що забезпечують оптимізацію тривалості циклу постачання та продажу товарів i надання якісних торговельних послуг, що підвищить ефективність управління та діяльності торговельних підприємств, а, отже, й ефективної діяльноті торговельних підприємств СК.

Conclusions. The investigation of process management as a factor of improving the effective functioning of trade consumer cooperation enterprises makes it possible to identify scientific and applied problems including the change in the way of thinking, particularly, 
awareness of the enterprise activity in the context of business processes that are dominant for trade enterprises. At the same time, the advantage of process management is its focus on the end results of effective activity within each business process and the effective process provision in order to meet the consumers needs. Implementation of process management is the main management task, the solution of which contributes to the determination of the business processes implementation mechanisms providing optimization of the duration of delivery cycle and sale of goods and quality trade services provision as well as effective trade consumer cooperation enterprises activity.

\section{Список використаної літератури}

1. Свстафієва Н. С. Удосконалення системи планування діяльності підприємств споживчої кооперації України. URL: www.vkapravyj @ yandex.ru (дата перегляду: 03.06.16).

2. Макухіна Н. О. Управління комерційною діяльністю торговельних підприємств на основі вдосконалення інформаційного забезпечення: автореф. дис. ... канд. екон. наук: спец. 08.00.04 / Львів. комерц. акад. Львів, 2008. 20 с.

3. Семів С. Р. Таксонометричний аналіз конкурентоспроможності підприємств споживчої кооперації у відкритій економіці. Вісн. Львів. комерційна акад. Серія економічна. 2001. Вип. 11. С. 202-211.

4. Каршаков В. П. Практические методы совершенствования системы менеджмента качества. Методы менеджмента качества. 2001. № 6. С. 8-10.

5. Семів С. Р. Конкурентоспроможність підприємств споживчої кооперації в умовах відкритої економіки: автореф. дис. ... канд. екон. наук: спец. 08.05.01 «Світове господарство і міжнародні економічні відносини» / Київ. нац. ун-т ім. Т. Шевченка. Київ, 2001. 20 с.

6. Про споживчу кооперацію: Закон України. Відомості Верховної Ради України (ВВР). 1992. № 30. C. 414.

7. Сторожук В. П. Управління підприємствами споживчої кооперації на засадах функціонального підходу: автореф. дис. ... канд. екон. наук: спец. 08.06.01 «Економіка, організація та управління підприємствами» / Донец. держ. ун-т економіки і торгівлі ім. М. Туган-Барановського. Донецьк, 2006. 23 c.

8. Zwicker J., Fettke P., Loos P. The six core elements of business process management. Handbook on Business Process Management. 2011. Vol. 2.

9. Malik T. S. Process Management. 2009. 306 p.

10. Рибалко Л. А. Формування системи управління якістю споживчої кооперації України: автореф. дис. ... канд. екон. наук: спец. 08.00.04 «Економіка та управління підприємствами (за видами економічної діяльності)» / Полтав. ун-т споживчої кооп. України. Полтава, 2008. 20 с.

11. Ночовна Ю. О. Організація управлінського обліку на хлібопекарних підприємствах споживчої кооперації: дис. ... канд. екон. наук / Полтав. ун-т споживчої кооп. України. Полтава, 2009. 215 с.

\section{References}

1. Yevstafiieva N. S. Udoskonalennia systemy planuvannia diialnosti pidpryiemstv spozhyvchoi kooperatsii Ukrainy. URL: www.vkapravyj@yandex.ru (data perehliadu: 03.06.16).

2. Makukhina N. O. Upravlinnia komertsiinoiu diialnistiu torhovelnykh pidpryiemstv na osnovi vdoskonalennia informatsiinoho zabezpechennia: avtoref. dys. ... kand. ekon. nauk: spets. 08.00.04 / Lviv. komerts. akad. Lviv, 2008. 20 p.

3. Semiv S. R. Taksonometrychnyi analiz konkurentospromozhnosti pidpryiemstv spozhyvchoi kooperatsii u vidkrytii ekonomitsi. Visn. Lviv. komertsiina akad. Seriia ekonomichna. 2001. Vyp. 11. P. 202-211.

4. Karshakov V. P. Praktycheskye metodы sovershenstvovanyia systemы menedzhmenta kachestva. Metod menedzhmenta kachestva. 2001. № 6. P. 8-10.

5. Semiv S. R. Konkurentospromozhnist pidpryiemstv spozhyvchoi kooperatsii $\mathrm{v}$ umovakh vidkrytoi ekonomiky: avtoref. dys. ... kand. ekon. nauk: spets. 08.05.01 "Svitove hospodarstvo i mizhnarodni ekonomichni vidnosyny" / Kyiv. nats. un-t im. T. Shevchenka. Kyiv, 2001. 20 p.

6. Pro spozhyvchu kooperatsiiu: Zakon Ukrainy. Vidomosti Verkhovnoi Rady Ukrainy (VVR). 1992. № 30. P. 414.

7. Storozhuk V. P. Upravlinnia pidpryiemstvamy spozhyvchoi kooperatsii na zasadakh funktsionalnoho pidkhodu: avtoref. dys. ... kand. ekon. nauk: spets. 08.06.01 "Ekonomika, orhanizatsiia ta upravlinnia pidpryiemstvamy" / Donets. derzh. un-t ekonomiky i torhivli im. M. Tuhan-Baranovskoho. Donetsk, 2006. $23 \mathrm{p}$.

8. Zwicker J., Fettke P., Loos P. The six core elements of business process management. Handbook on Business Process Management. 2011. Vol. 2.

9. Malik T. S. Process Management. 2009. 306 p.

10. Rybalko L. A. Formuvannia systemy upravlinnia yakistiu spozhyvchoi kooperatsii Ukrainy: avtoref. dys. ... kand. ekon. nauk: spets. 08.00.04 "Ekonomika ta upravlinnia pidpryiemstvamy (za vydamy ekonomichnoi diialnosti)" / Poltav. un-t spozhyvchoi koop. Ukrainy. Poltava, 2008. 20 p.

11. Nochovna Yu. O. Orhanizatsiia upravlinskoho obliku na khlibopekarnykh pidpryiemstvakh spozhyvchoi kooperatsii: dys. ... kand. ekon. nauk / Poltav. un-t spozhyvchoi koop. Ukrainy. Poltava, 2009. 215 p. 